\title{
Comparison of CP-PC-SAFT and SAFT-VR-Mie in Predicting Phase Equilibria of Binary Systems Comprising Gases and 1-Alkyl-3-methylimidazolium Ionic Liquids
}

\author{
Asaf Chiko ${ }^{1}$, Ilya Polishuk ${ }^{1, *}$, Esteban Cea-Klapp ${ }^{2}$ and José Matías Garrido ${ }^{2, *(D)}$ \\ 1 Department of Chemical Engineering, Ariel University, Ariel 40700, Israel; asafck9@gmail.com \\ 2 Departamento de Ingeniería Química, Universidad de Concepción, Concepción 4070386, Chile; \\ estebancea-klapp@udeq.cl \\ * Correspondence: polishuk@ariel.ac.il (I.P.); josemagarrido@udec.cl (J.M.G.); \\ Tel.: +972-3-9066-346 (I.P.); +56-41-220-3662 (J.M.G.)
}

\section{check for}

updates

Citation: Chiko, A.; Polishuk, I.; Cea-Klapp, E.; Garrido, J.M. Comparison of CP-PC-SAFT and SAFT-VR-Mie in Predicting Phase Equilibria of Binary Systems Comprising Gases and 1-Alkyl-3-methylimidazolium Ionic Liquids. Molecules 2021, 26, 6621. https://doi.org/10.3390/ molecules26216621

Academic Editor: Alessandra Gentili

Received: 9 October 2021

Accepted: 29 October 2021

Published: 1 November 2021

Publisher's Note: MDPI stays neutral with regard to jurisdictional claims in published maps and institutional affiliations.

Copyright: (c) 2021 by the authors. Licensee MDPI, Basel, Switzerland. This article is an open access article distributed under the terms and conditions of the Creative Commons Attribution (CC BY) license (https:/ / creativecommons.org/licenses/by/ $4.0 /)$.

\begin{abstract}
This study compares performances of the Critical Point-based revision of PerturbedChain SAFT (CP-PC-SAFT) and the SAFT of Variable Range and Mie Potential (SAFT-VR-Mie) in predicting the available data on VLE, LLVE, critical loci and saturated phase densities of systems comprising $\mathrm{CO}, \mathrm{O}_{2}, \mathrm{CH}_{4}, \mathrm{H}_{2} \mathrm{~S}, \mathrm{SO}_{2}$, propane, the refrigerants R22, R23, R114, R124, R125, R125, R134a, and R1234ze(E) and ionic liquids (ILs) with 1-alkyl-3-methylimidazolium $\left(\left[\mathrm{C}_{\mathrm{n}} \mathrm{mim}\right]^{+}\right)$cations and bis(trifluoromethanesulfonyl)imide $\left(\left[\mathrm{NTf}_{2}\right]^{-}\right)$, tetrafluoroborate $\left(\left[\mathrm{BF}_{4}\right]^{-}\right)$and hexafluorophosphate $\left(\left[\mathrm{PF}_{6}\right]^{-}\right)$anions. Both models were implemented in the entirely predictive manner with $k_{12}=0$. The fundamental Global Phase Diagram considerations of the IL systems are discussed. It is demonstrated that despite a number of quantitative inaccuracies, both models are capable of reproducing the regularities characteristic for the considered systems, which makes them suitable for preliminary estimation of selectivity of the ILs in separating various gases.
\end{abstract}

Keywords: predictive modeling; SAFT; ionic liquids

\section{Introduction}

Ionic liquids (ILs) are organic salts whose melting points are below $100{ }^{\circ} \mathrm{C}$. Due to their negligible vapor pressures, ILs are considered as green solvents. Moreover, the selectivity of ILs in separating various compounds, including gases, attach them by significant practical importance. A number of possible combinations between cations and anions of ILs is practically unlimited. Such a variety of systems cannot be investigated experimentally. Besides that, purities of laboratory samples are typically much better than of industrial solvents, which can result in unignorable difference between literature data and actual phase equilibria in industrial equipment. Moreover, due to the high viscosities of ILs, there is no guarantee that their real solvent capacities in industrial equipment always reach equilibria values. At times, there are noticeable deviations between different laboratory measurements of phase equilibria in the same ILs systems.

These reasons emphasize a primary importance of developing and validating thermodynamic approaches capable of estimating phase equilibria and other properties of mixtures comprising ILs with reasonable accuracy in the entirely predictive manner. In this respect, it should be emphasized that the thermodynamic properties of real fluids are influenced by various molecular phenomena, which currently cannot be appropriately treated, even by the most advanced theoretical approaches. Moreover, their application in systems of non-ordinary fluids such as ILs present a particularly challenging test. Bearing in mind a potentially high uncertainty of the available experimental data on ILs systems used for validation of thermodynamic models, it seems expedient to place major attention to their overall robustness and predictive capacity rather than to the precision in local fitting of particular datasets. 
Implementations of various thermodynamic approaches for modeling phase behavior in the IL systems were scored by several comprehensive reviews, see, for example [1-3]. Among the predictive approaches, the Conductor-Like Screening Model for Real Solvents (COSMO-RS) [4-8] and the Universal Quasichemical Functional-group Activity Coefficients model extended to ILs (UNIFAC-IL) [9] should be acknowledged. These models aim at estimating phase equilibria rather other thermodynamic properties, such as densities, heat capacities and sound velocities. Comparing to them, the equation of state (EoS) approaches relating pressure to temperature and volume have a more universal character. Thus far, numerous applications of Cubic EoSs (see for example [10-27]) and various versions of models belonging to a more theoretically advanced family of Statistical Association Fluid Theory (SAFT) (see for example [28-37]) for describing systems of ILs were reported in the literature. Most of these contributions have fitted the EoS approaches to the available data on mixtures using binary adjustable parameters. Although such practice substantially improves an agreement between the experimental and calculated data, it affects the predictive character of the models and hinders evaluation of their overall robustness and reliability. At the same time, some studies [38-42] have applied the EoS approaches to the systems of ILs in the predictive manner, while keeping zero or universal substance-independent values of the binary parameter $k_{12}$. The basic principle of EoS models is utilizing an input of available experimental data to produce an output of predicted data. As the input required by any particular EoS is smaller and the obtained output is larger, its predictive value becomes higher. Accuracies of the Critical Point-based revision of Perturbed-Chain SAFT (CP-PC-SAFT) [43] and the SAFT of Variable Range and Mie Potential (SAFT-VR-Mie) [44] in estimating the elevated pressure densities and auxiliary thermodynamic properties attach these models by a particularly high degree of universality.

This study examines the performances of CP-PC-SAFT and SAFT-VR-Mie in their maximal possible level of predictivity. For each model, the input information contains only three pure compound data or six data per binary system, without any preliminary consideration of the binary data. Basing on this small amount of the input information, the models are applied for predicting vapor-liquid equilibria (VLE), liquid-liquid-vapor equilibria (LLVE), critical loci and saturated phase densities of systems comprising several industrially important gases and the ILs with 1-alkyl-3-methylimidazolium $\left(\left[\mathrm{C}_{\mathrm{n}} \mathrm{mim}\right]^{+}\right)$ cations $(n=2,4,6,8)$ and bis(trifluoromethanesulfonyl)imide $\left(\left[\mathrm{NTf}_{2}\right]^{-}\right)$, tetrafluoroborate $\left(\left[\mathrm{BF}_{4}\right]^{-}\right)$and hexafluorophosphate $\left(\left[\mathrm{PF}_{6}\right]^{-}\right)$anions.

\section{Theory}

Full descriptions of CP-PC-SAFT and SAFT-VR-Mie are available elsewhere [43,44]. Therefore, here, some of their most relevant details are briefly discussed. Generally speaking, SAFT models express the residual Helmholtz energy $A^{\text {res }}$ as a sum of contributions representing different inter-molecular interactions as functions of temperature $(T)$ and molar volume $(v)$. Having an expression for $A^{\text {res }}$, the EoS relating pressure $(P)$ with $T$ and $v$ can be obtained:

$$
P=\frac{R T}{v}-\left(\frac{\partial A^{r e s}}{\partial v}\right)_{T}
$$

Several SAFT approaches, among them the initial version of PC-SAFT [45], exhibit certain undesired numerical pitfalls, such as predicting negative heat capacities [46] at high pressures and the additional unrealistic pure compound phase splits [47,48]. The latter phenomenon may seriously affect their accuracies in predicting properties of heavy compounds such as ILs and their mixtures [49-51]. In addition, SAFT models typically cannot represent critical pressures, temperatures, and saturated liquid densities in a simultaneously accurate manner [52,53]. To solve all these problems, CP-PC-SAFT [43] majorly revised the initial version of PC-SAFT [45]. This revision allows a standardized numerical solution of three molecular parameters, namely $m$ (the effective number of segments), $\sigma$ (the segment diameter, $\AA$ ), and $\varepsilon / k_{B}$ (the potential depth divided by Boltzmann constant, 
K) at critical temperature $\left(T_{c}\right)$, critical pressure $\left(P_{c}\right)$ and the triple point liquid density, applying the critical point conditions as follows:

$$
\begin{gathered}
\left(\frac{\partial P}{\partial v}\right)_{T c}=\left(\frac{\partial P^{2}}{\partial^{2} v}\right)_{T c}=\left.0\right|_{v_{c, E o S}=\delta v_{c}} \\
P_{c, E o S}=P_{c} \\
\rho_{L, E o S}=\left.\rho_{L, \text { experimental }}\right|_{\text {TriplePoint }}
\end{gathered}
$$

In Equation (2), $\delta$ is a substance-dependent critical volume displacement of the model and it is the fourth variable obtained by solving a system of four Equations (2)-(4). Thus, in the cases of compounds considered as non-associative and non-polar, the model requires only three pure compound data, namely the literature values of $T_{\mathcal{c}}, P_{c}$, and the triple point liquid density. In the current study, this information was obtained from the DIPPR databank [54].

Compared with CP-PC-SAFT, SAFT-VR-Mie is a more complicated approach, whose theoretical background is substantially more advanced. In addition to the three ordinary molecular parameters $m, \sigma$, and $\varepsilon / k_{B}$, it also includes $\lambda_{\mathrm{a}}$ (the attractive exponent of Mie potential), which is typically set to 6 , and $\lambda_{\mathrm{r}}$ (the repulsive exponent of Mie potential). Mejía et al. [55] proposed a set of particularly successful corresponding state (CS) correlations for the molecular parameters of SAFT-VR-Mie. Similarly to CP-PC-SAFT, this method requires three pure compound data, namely $T_{c}$, liquid density at $T / T_{c}=0.7$ and the acentric factor $(\omega)$. However, unlike CP-PC-SAFT, which rigorously obeys the literature values of both $T_{c}$ and $P_{c}$, it fits only $T_{c}$ and overestimates $P_{c}$. Table 1 lists the values of molecular parameters of the considered gases obtained by solving Equations (2)-(4) for CP-PC-SAFT and yielded by the CS approach of Mejía et al. [55] for SAFT-VR-Mie. The parameters of refrigerants were reported previously [56]. Overestimations of the literature [54] values of $P_{c}\left(\triangle P=P_{c, S A F T-V R-M i e} / P_{c, D I P P R}\right)$ by CS-SAFT-VR-Mie are also provided. As seen, in some cases, such as R23 and R134a, these overestimations are significant. Apparently, treatment of these compounds as non-polar and non-associative is an oversimplification. However, such an approach allows preserving a predictive parametrization of the model.

\begin{tabular}{|c|c|c|c|c|c|c|c|c|}
\hline \multirow[b]{2}{*}{ Compound } & \multicolumn{3}{|c|}{ CP-PC-SAFT } & \multicolumn{5}{|c|}{ CS-SAFT-VR-Mie $\left(\lambda_{\mathrm{a}}=6\right)$} \\
\hline & $m$ & $\sigma[\AA ̊]$ & $\begin{array}{c}\varepsilon / k_{\mathrm{b}} \\
{[\mathrm{K}]}\end{array}$ & $m$ & $\lambda_{\mathrm{r}}$ & $\sigma[\AA]$ & $\begin{array}{c}\varepsilon / k_{\mathrm{b}} \\
{[\mathrm{K}]}\end{array}$ & $\Delta P$ \\
\hline $\mathrm{CO}$ & 0.9983 & 3.6437 & 99.474 & 1 & 21.38 & 3.6901 & 132.62 & 1.082 \\
\hline $\mathrm{O}_{2}$ & 1.0546 & 3.3055 & 112.98 & 1 & 17.95 & 3.4069 & 144.09 & 1.091 \\
\hline $\mathrm{CH}_{4}$ & 1.0001 & 3.7476 & 142.51 & 1 & 16.40 & 3.7532 & 170.81 & 1.096 \\
\hline $\mathrm{H}_{2} \mathrm{~S}$ & 1.2332 & 3.4229 & 254.04 & 1 & 26.69 & 3.7944 & 401.27 & 1.114 \\
\hline $\mathrm{C}_{3} \mathrm{H}_{8}$ & 2.4144 & 3.3918 & 184.37 & 2 & 11.82 & 3.6531 & 205.57 & 1.084 \\
\hline $\mathrm{SO}_{2}$ & 3.3034 & 2.5760 & 189.41 & 2 & 15.74 & 3.0908 & 287.98 & 1.136 \\
\hline $\mathrm{R} 22$ & 3.2452 & 2.8738 & 163.48 & 2 & 14.426 & 3.4262 & 234.54 & 1.130 \\
\hline $\mathrm{R} 23$ & 4.2360 & 2.4331 & 120.42 & 2 & 16.838 & 3.1792 & 207.36 & 1.191 \\
\hline R114 & 2.0403 & 4.1115 & 224.78 & 2 & 16.119 & 4.1764 & 283.70 & 1.084 \\
\hline R123 & 3.0540 & 3.4931 & 207.02 & 2 & 18.043 & 4.1005 & 328.26 & 1.119 \\
\hline R124 & 3.3472 & 3.2173 & 173.12 & 2 & 18.416 & 3.9345 & 287.09 & 1.104 \\
\hline R125 & 3.2728 & 3.0946 & 149.66 & 2 & 19.755 & 3.7421 & 254.23 & 1.124 \\
\hline R134a & 3.9726 & 2.8502 & 154.00 & 2 & 21.627 & 3.6783 & 291.35 & 1.185 \\
\hline R1234ze(E) & 2.9581 & 3.3370 & 175.47 & 2 & 21.342 & 3.8871 & 296.26 & 1.134 \\
\hline
\end{tabular}

Table 1. Pure compound molecular parameters of CP-PC-SAFT and CS-SAFT-VR-Mie and overestimation of $P_{c}$ by CS-SAFT-VR-Mie $(\Delta P)$.

Unfortunately, the genuine critical constants of ILs are unavailable because these compounds decompose at the much lower temperatures. However, the molecular parameters 
of SAFT models can be obtained by solving them at three standardly selected density points, two at the lowest available isotherm and one at the highest one. The resulting values for the considered ILs, along with the predicted values of $T_{c}$ and $P_{c}$, are listed in Table 2. The CP-PC-SAFT parameters of ILs belonging to the $\left[\mathrm{C}_{\mathrm{n}}\right.$ mim] $\left[\mathrm{NTf}_{2}\right]$ homologies series were generalized by molecular weight $\left(M_{\mathrm{W}}\right)$ [39]. Following the Lennard-Jones potential, the SAFT-VR-Mie parameters $\lambda_{\mathrm{a}}$ and $\lambda_{\mathrm{r}}$ were set to 6 and 12. The estimations of densities in wide range of $T$ and $P$ yielded by both models are particularly accurate, and the deviations from data are typically comparable with experimental uncertainties [39,42]. As seen, SAFT-VR-Mie yields the higher values of $T_{c}$ and $P_{c}$ versus CP-PC-SAFT.

Table 2. The molecular parameters and critical constants of pure ILs yielded by SAFT-VR-Mie and CP-PC-SAFT [39,42].

\begin{tabular}{|c|c|c|c|c|c|c|c|c|c|c|}
\hline \multirow[b]{2}{*}{ Compound } & \multicolumn{5}{|c|}{ CP-PC-SAFT } & \multicolumn{5}{|c|}{ SAFT-VR-Mie $\left(\lambda_{\mathrm{a}}=6, \lambda_{\mathrm{r}}=12\right)$} \\
\hline & $m$ & $\sigma(\AA)$ & $\varepsilon / k_{B}(\mathrm{~K})$ & $T_{c}(\mathrm{~K})$ & $P_{c}$ (bar) & $m$ & $\sigma(\AA)$ & $\varepsilon / k_{B}(\mathrm{~K})$ & $T_{c}(\mathrm{~K})$ & $P_{c}$ (bar) \\
\hline$\left[\mathrm{C}_{8} \operatorname{mim}\right]\left[\mathrm{NTf}_{2}\right]$ & \multirow{4}{*}{\multicolumn{3}{|c|}{$\begin{array}{c}m=-7.2461+0.0408 M_{\mathrm{w}} \\
\sigma=3.5748-0.00012 M_{\mathrm{w}} \\
\varepsilon / k_{\mathrm{b}}=382.8867-0.2656 M_{\mathrm{w}}\end{array}$}} & 834.2 & 10.32 & 9.3326 & 3.8650 & 343.69 & 1030.0 & 14.39 \\
\hline$\left[\mathrm{C}_{6} \operatorname{mim}\right]\left[\mathrm{NTf}_{2}\right]$ & & & & 841.8 & 12.08 & 8.7544 & 3.8168 & 341.63 & 1007.0 & 15.94 \\
\hline$\left[\mathrm{C}_{4} \mathrm{mim}\right]\left[\mathrm{NTf}_{2}\right]$ & & & & 846.1 & 14.28 & 8.1763 & 3.7685 & 351.58 & 1017.7 & 18.36 \\
\hline$\left[\mathrm{C}_{2} \operatorname{mim}\right]\left[\mathrm{NTf}_{2}\right]$ & & & & 846.0 & 17.05 & 7.5981 & 3.7203 & 370.44 & 1051.1 & 21.76 \\
\hline$\left[\mathrm{C}_{8} \mathrm{mim}\right]\left[\mathrm{BF}_{4}\right]$ & 8.4287 & 3.5692 & 298.31 & 897.6 & 18.35 & 6.8632 & 3.8455 & 381.50 & 1051.8 & 22.60 \\
\hline$\left[\mathrm{C}_{4} \mathrm{mim}\right]\left[\mathrm{PF}_{6}\right]$ & 6.8113 & 3.5923 & 325.28 & 929.0 & 25.10 & 5.4343 & 3.8993 & 418.22 & 1074.9 & 30.26 \\
\hline$\left[\mathrm{C}_{4} \mathrm{mim}\right]\left[\mathrm{BF}_{4}\right]$ & 5.9300 & 3.6426 & 338.02 & 930.0 & 29.04 & 4.9271 & 3.8976 & 426.40 & 1062.2 & 34.09 \\
\hline
\end{tabular}

\section{Results and Discussion}

As discussed [41,42], the pressure dependencies of densities of the considered ILs decrease with reducing the $n$-alkyl chain of $\left[\mathrm{C}_{\mathrm{n}} \mathrm{mim}\right]^{+}$cation and lessening the anion's size from $\left[\mathrm{NTf}_{2}\right]^{-}$to $\left[\mathrm{PF}_{6}\right]^{-}$and then to $\left[\mathrm{BF}_{4}\right]^{-}$. It can also be seen (Table 2) that the imaginary $T_{c}$ and $P_{c}$ values of ILs generated by CP-PC-SAFT increase with decrease of the pressure dependencies. SAFT-VR-Mie partially reproduces this inter-relation as well. According to the general Global Phase Diagram (GPD) considerations, as the gap between the critical points of solutes and solvents decrease, the systems become more symmetric, their phase splits become narrower, resulting thus in higher molar solubilities. Consequently, the degree of asymmetry in fluid systems is defined by the $T_{c}$ and $P_{c}$ values of both the ILs and the compounds dissolved in them. In particular, the lower critical constants of the IL solvents and the higher critical constants of the solutes increase the system symmetries and thus-the solubilities.

So far [41,42], a validity of this regularity was demonstrated for the IL systems of various non-associating compounds, such as refrigerants, aliphatic, aromatic, and oxygenated hydrocarbons. Figure 1 shows that the IL systems of $\mathrm{CO}, \mathrm{O}_{2}, \mathrm{CH}_{4}, \mathrm{H}_{2} \mathrm{~S}$ and $\mathrm{SO}_{2}$ also obey these regularities. As seen, the solvent capacities of the $\left[\mathrm{NTf}_{2}\right]^{-} \mathrm{ILs}$ are higher than of $\left[\mathrm{PF}_{6}\right]^{-}$and $\left[\mathrm{BF}_{4}\right]^{-}$. Besides that, elongation of the cation $n$-alkyl chain also increases the solubilities, while the higher $T_{\mathcal{c}}$ and $P_{c}$ values of the gases result in an increase of their solubilities. In can also be seen that both CP-PC-SAFT and SAFT-VR-Mie are, in general, capable of predicting these tendencies without adjusting the binary parameter $k_{12}$. The only exception is the results of CP-PC-SAFT for the $\mathrm{SO}_{2}$ systems (Figure 1E), which do not exhibit any clear tendency.

Nevertheless, this model predicts more accurately phase equilibria in the systems of $\mathrm{CO}$ (Figure $1 \mathrm{~A}$ ) and $\mathrm{O}_{2}$ (Figure $1 \mathrm{~B}$ ), along with solubility of $\mathrm{CH}_{4}$ in $\left[\mathrm{C}_{4} \mathrm{mim}\right]\left[\mathrm{PF}_{6}\right]$ (Figure 1C). At the same time, SAFT-VR-Mie is advantageous in the case of its solubility in $\left[\mathrm{C}_{4} \mathrm{mim}\right]\left[\mathrm{NTf}_{2}\right]$. Besides that, accuracies of both models in predicting the solubilities of $\mathrm{H}_{2} \mathrm{~S}$ in the considered ILs at $313.15 \mathrm{~K}$ are reasonably good (Figure 1D). CP-PC-SAFT tends to slightly underestimate them, while SAFT-VR-Mie minorly overpredicts these data. 

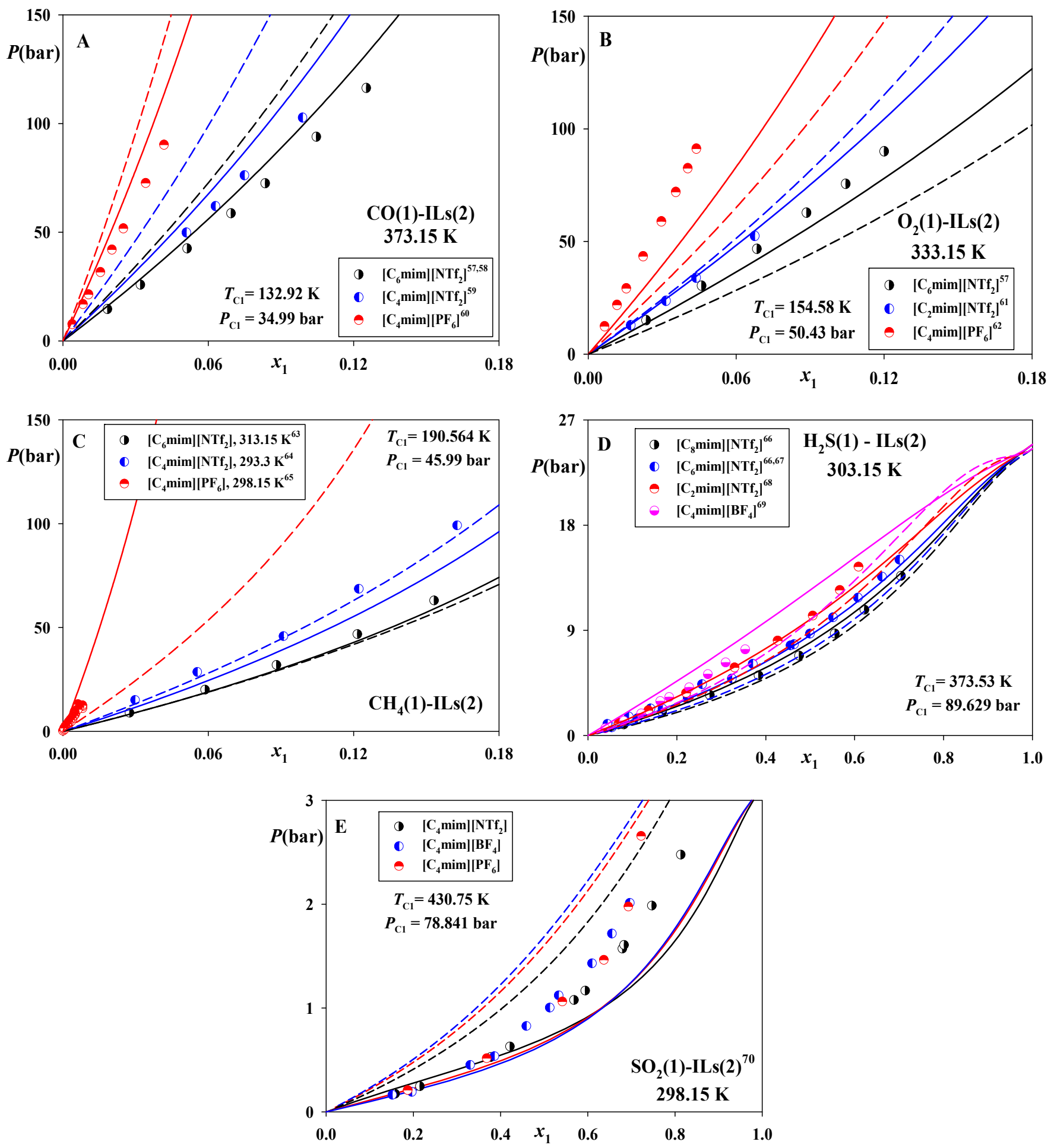

Figure 1. Solubilities of $\mathrm{CO}, \mathrm{O}_{2}, \mathrm{CH}_{4}, \mathrm{H}_{2} \mathrm{~S}$ and $\mathrm{SO}_{2}$ in $\left[\mathrm{C}_{2} \mathrm{mim}\right]\left[\mathrm{NTf}_{2}\right],\left[\mathrm{C}_{4}\right.$ mim] $\left[\mathrm{NTf}_{2}\right],\left[\mathrm{C}_{6}\right.$ mim] $\left[\mathrm{NTf}_{2}\right],\left[\mathrm{C}_{8} \mathrm{mim}\right]\left[\mathrm{NTf}_{2}\right]$, $\left[\mathrm{C}_{4} \mathrm{mim}\right]\left[\mathrm{BF}_{4}\right]$ and $\left[\mathrm{C}_{4} \mathrm{mim}\right]\left[\mathrm{PF}_{6}\right]$. Points-experimental data [57-70]. Solid lines-predictions of CP-PC-SAFT, dashed lines-predictions of SAFT-VR-Mie. $k_{12}=0$ for both models. $x 1$-mole fraction of the solute gas.

A success of CP-PC-SAFT and SAFT-VR-Mie in estimating solubility trends of refrigerants in the considered ILs was already discussed [42]. In the current study a more detailed comparison of their predictions for phase equilibria in these systems is presented. Figure 2A-C demonstrates that CP-PC-SAFT accurately predicts VLE in the systems of R22 and slightly underestimates them in $\mathrm{R} 23-\left[\mathrm{C}_{2} \mathrm{mim}_{[}\left[\mathrm{NTf}_{2}\right]\right.$ (Figure 2D). At the same time, 
this model yields accurate results for VLE and LLVE in the system $\mathrm{R} 23-\left[\mathrm{C}_{4} \mathrm{mim}\right]\left[\mathrm{PF}_{6}\right]$ and overestimates its LLE at high pressures (Figure 2E).
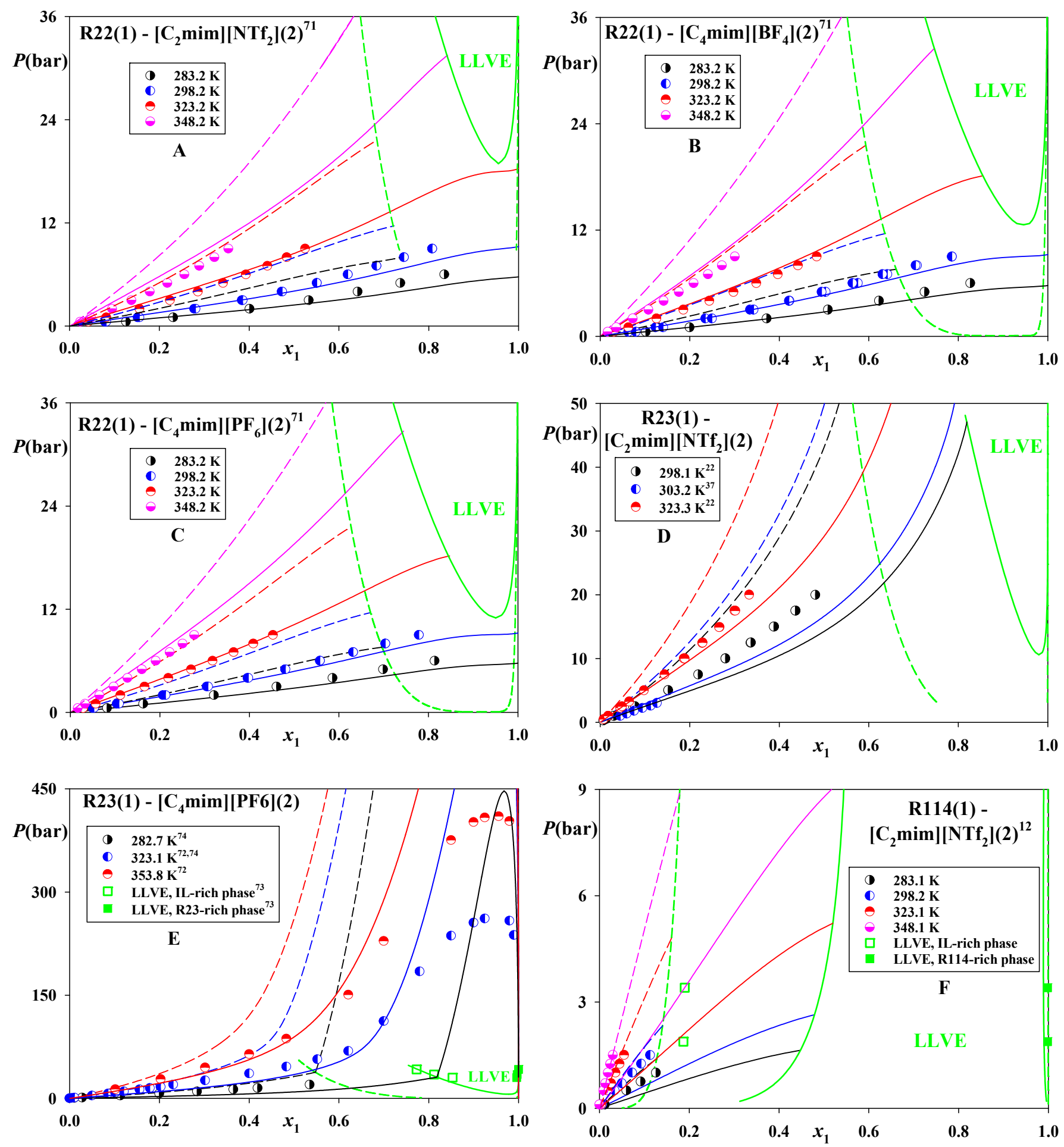

Figure 2. Phase equilibria in the systems of R22, R23 and R114 dissolved in $\left[\mathrm{C}_{2}\right.$ mim] $\left[\mathrm{NTf}_{2}\right],\left[\mathrm{C}_{4} \mathrm{mim}\right][\mathrm{BF} 4]$ and $\left[\mathrm{C}_{4} \mathrm{mim}^{\mathrm{mim}}[\mathrm{PF}]\right.$. Points-experimental data [12,22,37,71-74]. Solid lines-predictions of CP-PC-SAFT, dashed lines-predictions of SAFTVR-Mie. $k_{12}=0$ for both models.

It can also be seen that SAFT-VR-Mie exhibits an inferior performance overestimating these data. At the same time, the wider phase splits yielded by this model result in more accurate in predictions of VLE and LLVE in R114- $\left[\mathrm{C}_{2} \mathrm{mim}_{[}\left[\mathrm{NTf}_{2}\right]\right.$ (Figure $2 \mathrm{~F}$ ). 
Figure 3 demonstrates that CP-PC-SAFT accurately predicts both the VLE and LLVE in R124-[C $\left.\mathrm{C}_{2} \mathrm{mim}\right]\left[\mathrm{NTf}_{2}\right]$ (Figure 3A) and slightly overestimates VLE in systems of R125 and propane (Figure 3B-F). At the same, it overestimates the available LLVE data (Figure 3B,D) in a more significant manner.
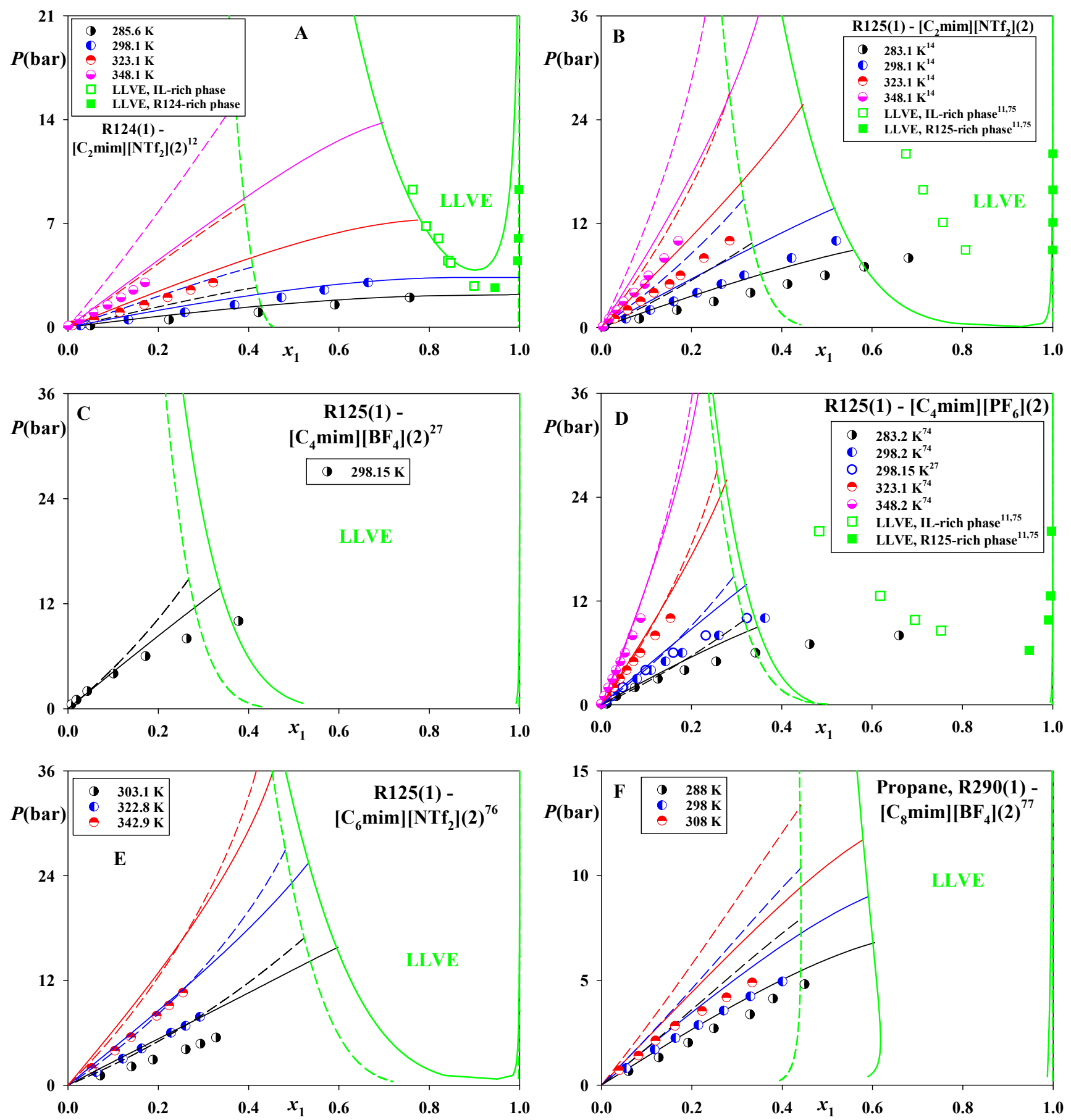

Figure 3. Phase equilibria in the systems of R124, R125, and propane (R290) dissolved in $\left[\mathrm{C}_{2} \operatorname{mim}\right]\left[\mathrm{NTf}_{2}\right],\left[\mathrm{C}_{6} \mathrm{mim}\right]\left[\mathrm{NTf}_{2}\right]$, $\left[\mathrm{C}_{4} \mathrm{mim}\right]\left[\mathrm{BF}_{4}\right],\left[\mathrm{C}_{8} \mathrm{mim}\right]\left[\mathrm{BF}_{4}\right]$ and $\left[\mathrm{C}_{4} \mathrm{mim}\right]\left[\mathrm{PF}_{6}\right]$. Points—experimental data $[11,12,14,27,75-77]$. Solid lines-predictions of CP-PC-SAFT, dashed lines-predictions of SAFT-VR-Mie. $K_{12}=0$ for both models.

For some of the presented systems (see Figure 3A-C,F) SAFT-VR-Mie predicts substantially wider ranges of phase splits, which results in inferior accuracy in comparison with CP-PC-SAFT. For other systems (see Figure 3D,E), the results of both models are similar. 
Figure 4A-D show that CP-PC-SAFT yields reasonably good predictions of VLE and LLVE in the systems of R134a, tending to slightly underestimate them. At the same time, it overestimates the high-pressure LLE in R134a- $\left[\mathrm{C}_{6}\right.$ mim] $\left[\mathrm{NTf}_{2}\right]$ at $348.15 \mathrm{~K}$ (Figure 4C). Once again, SAFT-VR-Mie yields broader ranges of phase equilibria for these systems, which usually deteriorates its accuracy. At the same time, in the case of R134a$\left[\mathrm{C}_{8} \mathrm{mim}\right]\left[\mathrm{NTf}_{2}\right]$ (Figure $4 \mathrm{D}$ ) the performance of SAFT-VR-Mie is superior. Figure 4E,D demonstrate that both modes yield similarly accurate estimations for VLE in the systems R1234ze(E)- $\left[\mathrm{C}_{4} \mathrm{mim}\right]\left[\mathrm{PF}_{6}\right]$ and $-\left[\mathrm{C}_{8} \mathrm{mim}\right]\left[\mathrm{BF}_{4}\right]$. Remarkable, unlike other considered cases, for these systems SAFT-VR-Mie predicts slightly narrower ranges of VLE phase splits.
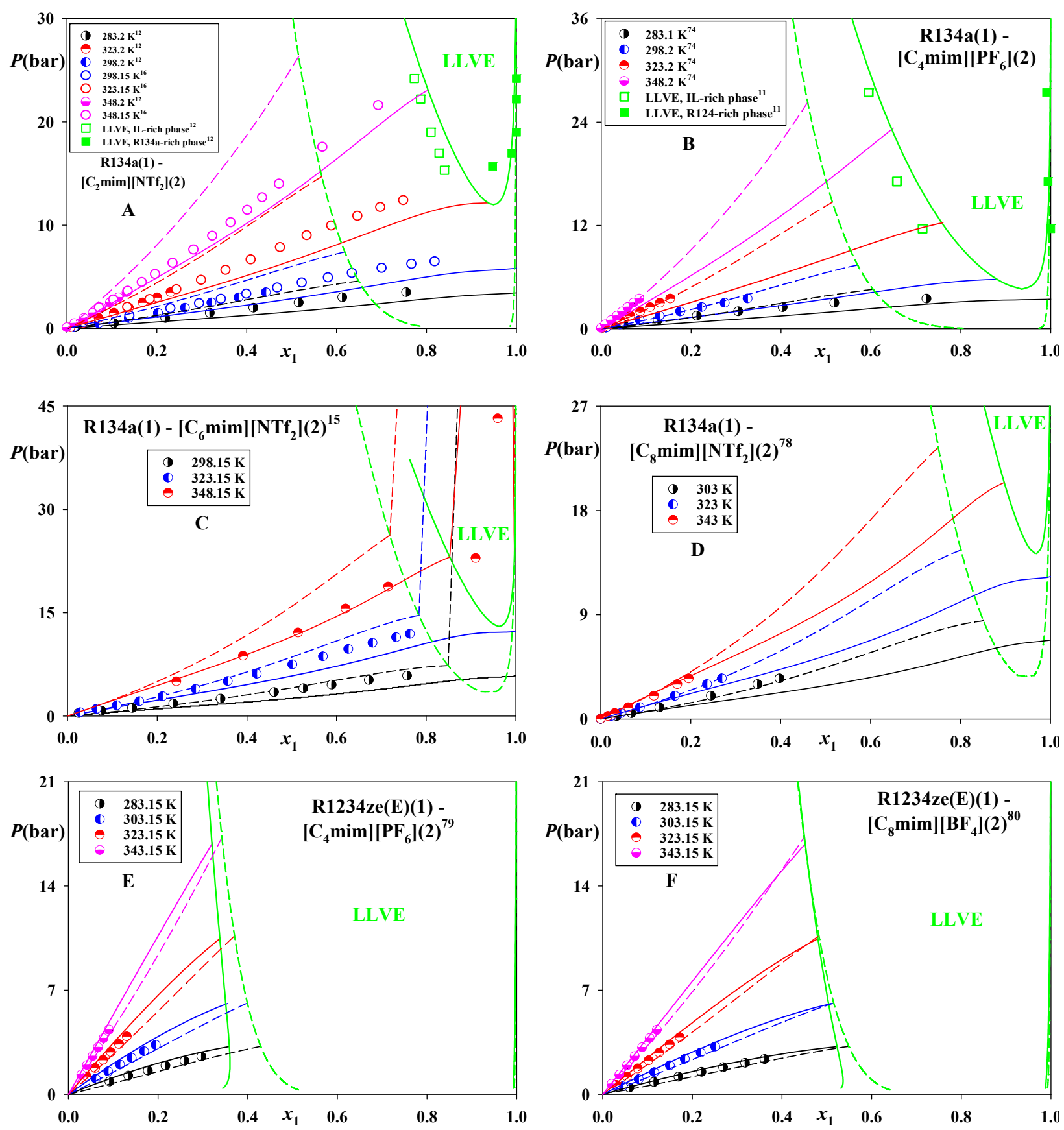

Figure 4. Phase equilibria in the systems of R134a and R1234ze(E) dissolved in $\left[\mathrm{C}_{2} \operatorname{mim}\right]\left[\mathrm{NTf}_{2}\right],\left[\mathrm{C}_{6} \mathrm{mim}\right]\left[\mathrm{NTf}_{2}\right]$, $\left[\mathrm{C}_{8} \mathrm{mim}\right]\left[\mathrm{NTf}_{2}\right],\left[\mathrm{C}_{8} \mathrm{mim}\right]\left[\mathrm{BF}_{4}\right]$, and $\left[\mathrm{C}_{4} \mathrm{mim}\right]\left[\mathrm{PF}_{6}\right]$. Points-experimental data $[11,12,15,16,74,78-80]$. Solid linespredictions of CP-PC-SAFT, dashed lines-predictions of SAFT-VR-Mie. $K_{12}=0$ for both models. 
Figure 5 exemplifies predictions of the saturated liquid phases densities along LLVE. As seen, the results of both models in predicting these challenging data are usually reasonably good. Remarkable, despite the significant differences between CP-PC-SAFT and SAFTVR-Mie in estimating the LLVE compositions of some systems (see Figures 2F, 3A, and 4B), their results of for the densities can be rather similar (see Figure 5A,C,F). Moreover, despite the nearly identical overestimations of the LLVE phase splits in R125- $\left[\mathrm{C}_{4} \mathrm{mim}\right]\left[\mathrm{PF}_{6}\right]$ (Figure 3D) by both models, the predictions of the pertinent densities are particularly accurate. At the same time, while CP-PC-SAFT accurately predicts both the compositions and the densities of R134a- $\left[\mathrm{C}_{2}\right.$ mim] $\left[\mathrm{NTf}_{2}\right]$ (Figures $4 \mathrm{~A}$ and $5 \mathrm{E}$ ), a major overestimation of the LLVE range by SAFT-VR-Mie affects its estimations of the densities as well. Besides that, it can be seen that both models are capable of predicting the barotropy effect in the system R123- $\left[\mathrm{C}_{4} \mathrm{mim}\right]\left[\mathrm{PF}_{6}\right]$ (Figure 3B). Remarkable, SAFT-VR-Mie estimates the barotropic point more accurately than CP-PC-SAFT.

Figure 6 depicts the critical loci in the systems of R134a and $\left[\mathrm{C}_{6} \mathrm{mim}\right]\left[\mathrm{NTf}_{2}\right],\left[\mathrm{C}_{2} \mathrm{mim}\right]\left[\mathrm{NTf}_{2}\right]$, and $\left[\mathrm{C}_{4} \mathrm{mim}\right]\left[\mathrm{PF}_{6}\right]$. Expectedly, the experimental critical pressures of these systems rise with a decrease of the Ils' compressibilities and the corresponding increase of their systems asymmetry. All these systems exhibit Type $\mathrm{V}$ behavior according to the classification of van Konynenburg and Scott [81,82].

As seen, CP-PC-SAFT correctly predicts both the topology of all these systems and the tendencies established by their critical data. Certain overestimations of the critical pressures ire not surprising while bearing in mind the results of this model for the available LLE data (Figure 4C). At the same time, SAFT-VR-Mie overestimates the critical loci in a much more significant manner. Figure 6 demonstrates that it correctly predicts the phase behavior of Type $\mathrm{V}$ only for the most symmetric R134a- $\left[\mathrm{C}_{6}\right.$ mim] $\left[\mathrm{NTf}_{2}\right]$ system.

For two more asymmetric systems of $\left[\mathrm{C}_{2} \mathrm{mim}\right]\left[\mathrm{NTf}_{2}\right]$, and $\left[\mathrm{C}_{4} \mathrm{mim}\right]\left[\mathrm{PF}_{6}\right]$, this model incorrectly estimates the behavior of Type III. This result also explains the shapes of LLVE and their densities yielded by SAFT-VR-Mie for these systems (see Figure 4A,B and Figure 5E,F), which do not exhibit a lower critical endpoint (LCEP). It can also be seen that SAFT-VR-Mie erroneously predicts the phase behavior of Type III for the system R124- $\left[\mathrm{C}_{2} \mathrm{mim}\right]\left[\mathrm{NTf}_{2}\right]$, while CP-PC-SAFT correctly estimates for it, Type V (see Figures 3A and 5C).
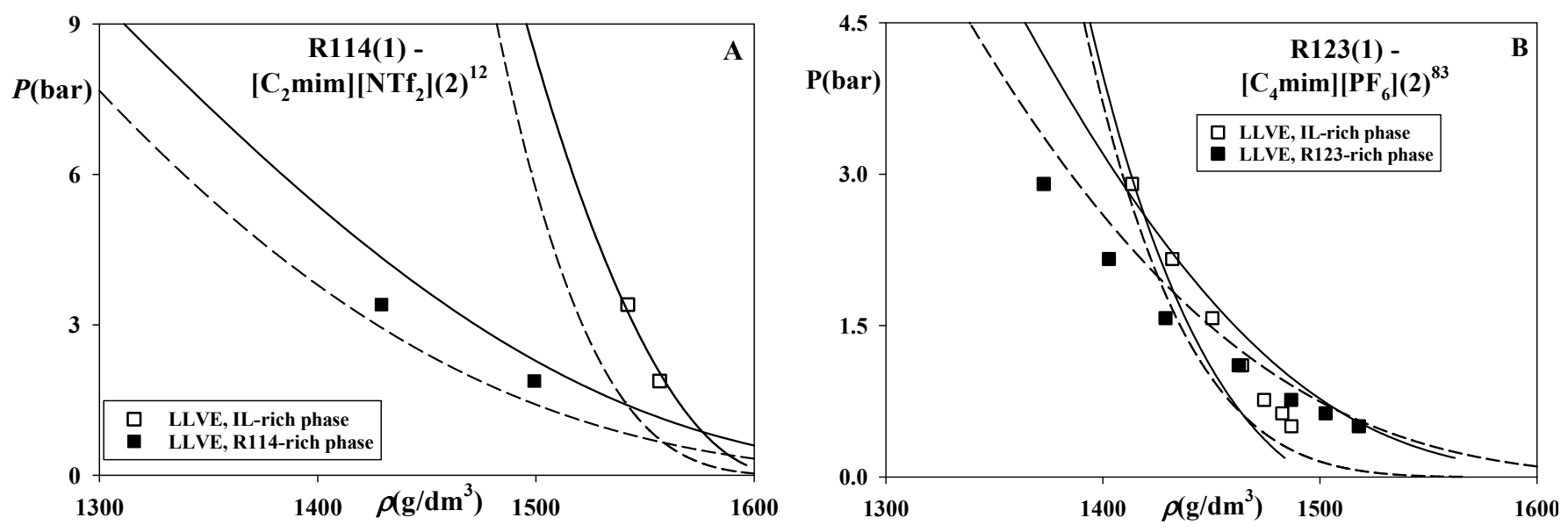

Figure 5. Cont. 

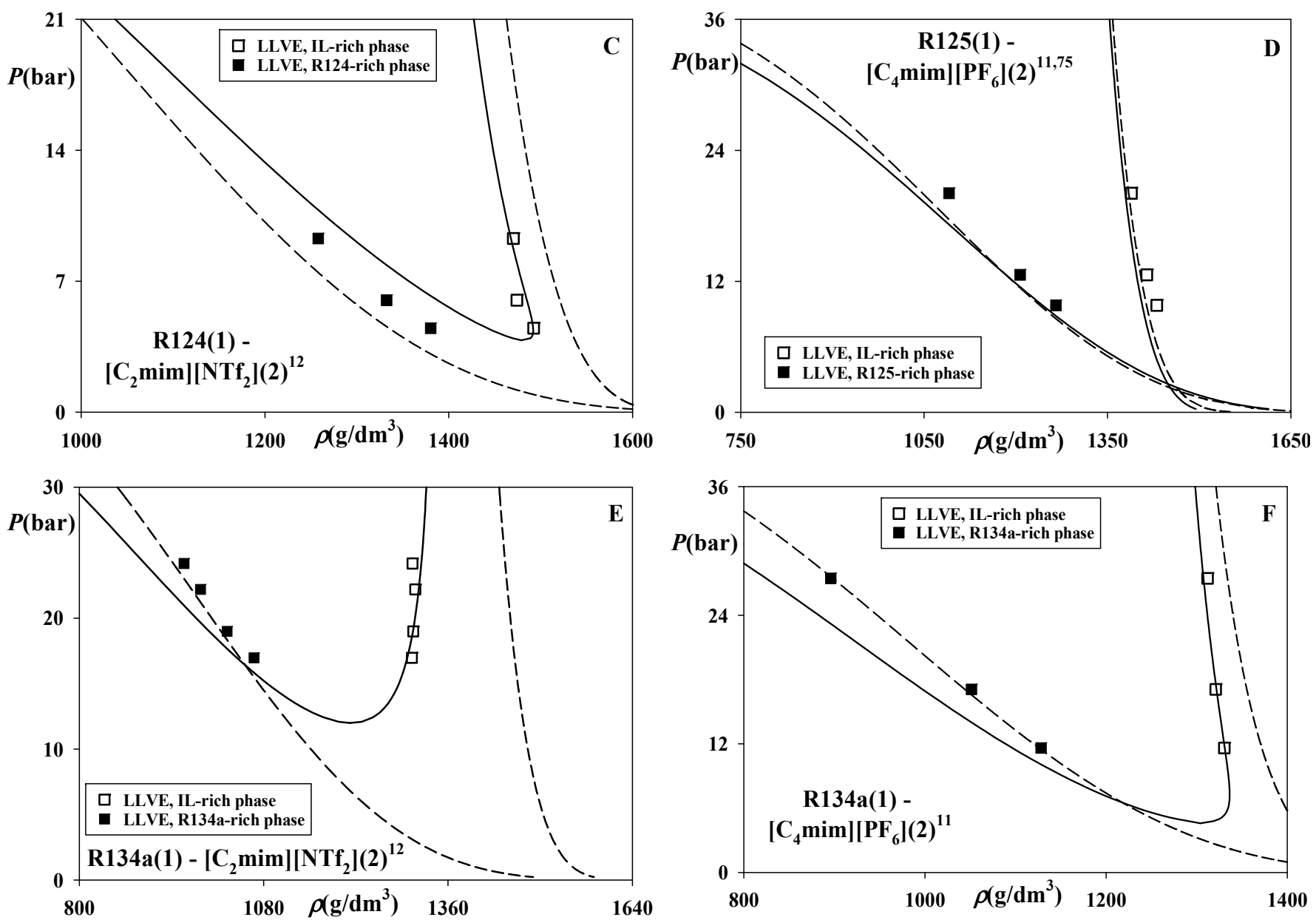

Figure 5. Densities of saturated liquid phases along LLVE in the systems of R114, R123, R124, R134a dissolved in $\left[\mathrm{C}_{2} \mathrm{mim}\right]\left[\mathrm{NTf}_{2}\right]$ and $\left[\mathrm{C}_{4} \mathrm{mim}\right]\left[\mathrm{PF}_{6}\right]$. Points-experimental data $[11,12,75,83]$. Solid lines-predictions of CP-PC-SAFT, dashed lines-predictions of SAFT-VR-Mie. $k_{12}=0$ for both models.

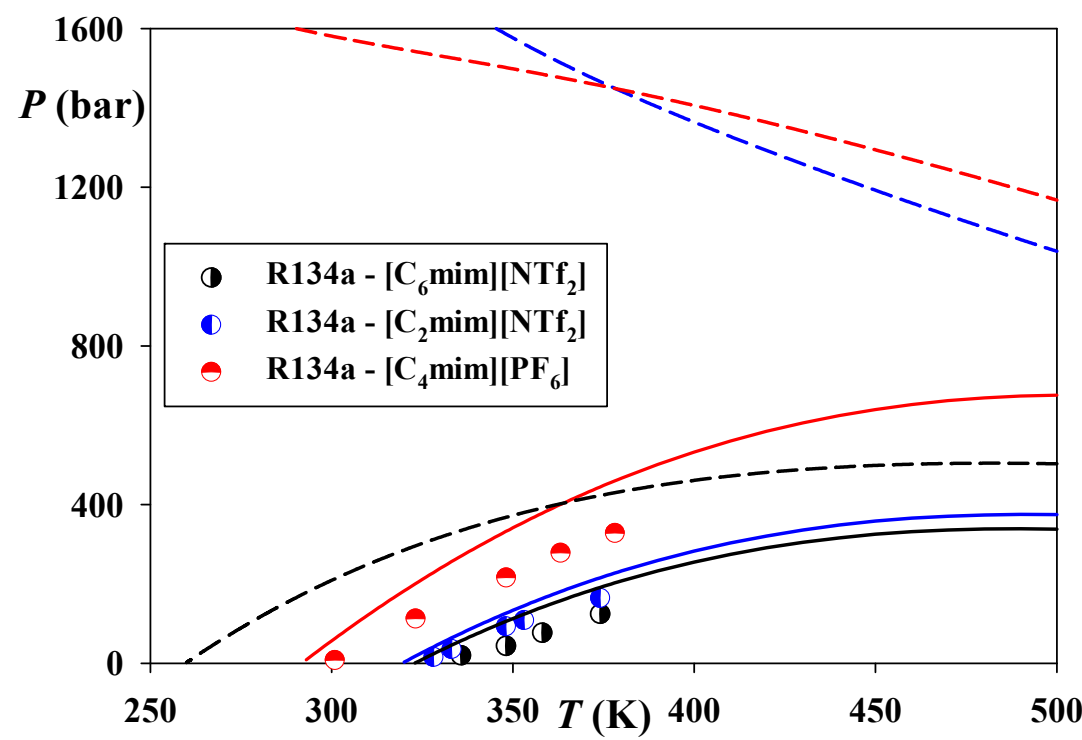

Figure 6. Critical loci in the systems of R134a and $\left[\mathrm{C}_{6} \mathrm{mim}\right]\left[\mathrm{NTf}_{2}\right],\left[\mathrm{C}_{2} \mathrm{mim}\right]\left[\mathrm{NTf}_{2}\right]$, and $\left[\mathrm{C}_{4} \mathrm{mim}\right]\left[\mathrm{PF}_{6}\right]$. Points-experimental data [84]. Solid lines—predictions of CP-PC-SAFT, dashed lines-predictions of SAFT-VR-Mie. $k_{12}=0$ for both models. 


\section{Conclusions}

This study compared performances of two molecularly based approaches, namely CP-PC-SAFT and SAFT-VR-Mie, in predicting the available data on VLE, LLVE, critical loci and saturated phase densities of systems of $\mathrm{CO}, \mathrm{O}_{2}, \mathrm{CH}_{4}, \mathrm{H}_{2} \mathrm{~S}, \mathrm{SO}_{2}$, propane, and the refrigerants R22, R23, R114, R124, R125, R125, R134a, and R1234ze(E) with $\left[\mathrm{C}_{2} \mathrm{mim}\right]\left[\mathrm{NTf}_{2}\right],\left[\mathrm{C}_{4} \mathrm{mim}\right]\left[\mathrm{NTf}_{2}\right],\left[\mathrm{C}_{6} \mathrm{mim}\right]\left[\mathrm{NTf}_{2}\right],\left[\mathrm{C}_{8} \mathrm{mim}\right]\left[\mathrm{NTf}_{2}\right],\left[\mathrm{C}_{4} \mathrm{mim}\right]\left[\mathrm{BF}_{4}\right],\left[\mathrm{C}_{8} \mathrm{mim}\right]\left[\mathrm{BF}_{4}\right]$, and $\left[\mathrm{C}_{4} \mathrm{mim}\right]\left[\mathrm{PF}_{6}\right] \mathrm{ILs}$. Both models were implemented to mixtures in an entirely predictive manner with $k_{12}=0$. In order to preserve a predictive character of the pure compound parameterization, all the compounds were treated as non-polar and non-associating. This approach can be assessed as oversimplification because some of the considered compounds are polar and associating. At the same time, these intermolecular interactions influence the values of the critical constants, and therefore their effects are still indirectly counted. Remarkably, in the cases of polar and possibly associating compounds, SAFT-VR-Mie yields higher overestimations of the critical pressures. It has been demonstrated that the systems of $\mathrm{CO}, \mathrm{O}_{2}, \mathrm{CH}_{4}, \mathrm{H}_{2} \mathrm{~S}$ and $\mathrm{SO}_{2}$ obey a regularity previously detected for the systems of refrigerants and other compounds, namely a rise of solubilities with an increase of the ILs' compressibilities. This regularity is explained by the fundamental GPD considerations. Since the imaginary $T_{c}$ and $P_{c}$ values of the more compressible ILs are lower, their systems are more symmetric, thus increasing the solubilities and vice versa. Similarly, the higher critical constants of solutes also reduce the asymmetry and increase the solubilities.

SAFT-VR-Mie is a more sophisticated model versus CP-PC-SAFT and its theoretical background is more advanced. Nevertheless, it appears that the GPD factors have a major influence on predicting phase equilibria in the IL systems. In particular, while CP-PC-SAFT rigorously obeys the literature values of both $T_{c}$ and $P_{c}$ of gases, SAFT-VR-Mie matches just the $T_{c}$ and overestimates the $P_{c}$. The latter is supposed to reduce the systems asymmetry. Nevertheless, being fitted to the same high-pressure density data of the considered ILs, SAFT-VR-Mie yields the higher $T_{c}$ and $P_{c}$ values versus CP-PC-SAFT. Unfortunately, at the current level of expertise, it does not seem possible to judge which IL critical constants sets are more realistic. Nevertheless, it has been demonstrated that the higher critical constants of ILs generated by SAFT-VR-Mie probably result in overestimating the ranges of phase splits and lead to an inferior accuracy in predicting phase equilibria in many systems compared with CP-PC-SAFT. However, in certain cases, both models yielded similar results. Moreover, some data, such as VLE in the systems R114- $\left[\mathrm{C}_{2} \mathrm{mim}\right]\left[\mathrm{NTf}_{2}\right]$ and R134a$\left[\mathrm{C}_{4} \mathrm{mim}\right]\left[\mathrm{PF}_{6}\right]$, along with the barotropic point of $\mathrm{R} 123-\left[\mathrm{C}_{4} \mathrm{mim}\right]\left[\mathrm{PF}_{6}\right]$, were predicted more accurately by SAFT-VR-Mie. At the same time, despite a number of quantitative inaccuracies, both models were capable of reproducing the regularities characteristic for the considered systems, which makes them suitable for preliminary estimation of selectivity of the ILs in separating various gases.

Author Contributions: Conceptualization, I.P.; methodology, I.P. and J.M.G.; software, A.C. and E.C.-K.; validation, A.C. and E.C.-K.; investigation, A.C., I.P., E.C.-K. and J.M.G.; data curation, I.P.; writing-original draft preparation, A.C. and I.P.; supervision, I.P. and J.M.G. All authors have read and agreed to the published version of the manuscript.

Funding: This research received no external funding.

Data Availability Statement: All the experimental data were obtained from the open sources and the relevant references were provided.

Conflicts of Interest: The authors declare no conflict of interest.

Sample Availability: All the CP-PC-SAFT and SAFT-VR-Mie codes written in Mathematica software are available from the authors. 


\section{References}

1. Lei, Z.; Dai, C.; Chen, B. Gas solubility in ionic liquids. Chem. Rev. 2014, 114, 1289-1326. [CrossRef]

2. Maia, F.M.; Tsivintzelis, I.; Rodriguez, O.; Macedo, E.A.; Kontogeorgis, G.M. Equation of state modelling of systems with ionic liquids: Literature review and application with the Cubic Plus Association (CPA) model. Fluid Phase Equilib. 2012, 332, 128-143. [CrossRef]

3. Domańska, U. Experimental data of fluid phase equilibria-Correlation and prediction models: A review. Processes 2019, 7, 277. [CrossRef]

4. Ferreira, A.R.; Freire, M.G.; Ribeiro, J.C.; Lopes, F.M.; Crespo, J.G.; Coutinho, J.A.P. An overview of the liquid-liquid equilibria of (ionic liquid + hydrocarbon) binary systems and their modeling by the conductor-like screening model for real solvents. Ind. Eng. Chem. Res. 2011, 50, 5279-5294. [CrossRef]

5. Ferreira, A.R.; Freire, M.G.; Ribeiro, J.C.; Lopes, F.M.; Crespo, J.G.; Coutinho, J.A.P. Overview of the liquid-liquid equilibria of ternary systems composed of ionic liquid and aromatic and aliphatic hydrocarbons, and their modeling by COSMO-RS. Ind. Eng. Chem. Res. 2012, 51, 3483-3507. [CrossRef]

6. Paduszyński, K. Extensive evaluation of the conductor-like screening model for real solvents method in predicting liquid-liquid equilibria in ternary systems of ionic liquids with molecular compounds. J. Phys. Chem. B 2018, 122, 4016-4028. [CrossRef] [PubMed]

7. Palomar, J.; Ferro, V.R.; Torrecilla, J.S.; Rodríguez, F. Density and molar volume predictions using COSMO-RS for ionic liquids. An approach to solvent design. Ind. Eng. Chem. Res. 2007, 46, 6041-6048. [CrossRef]

8. Paduszyński, K.; Królikowska, M. Extensive evaluation of performance of the COSMO-RS approach in capturing liquid-liquid equilibria of binary mixtures of ionic liquids with molecular compounds. Ind. Eng. Chem. Res 2020, 59, 11851-11863. [CrossRef]

9. Chen, Y.; Liu, X.; Woodley, J.M.; Kontogeorgis, G.M. Gas solubility in ionic liquids: UNIFAC-IL model extension. Ind. Eng. Chem. Res. 2020, 59, 16805-16821. [CrossRef]

10. Shariati, A.; Peters, C.J. High-pressure phase behavior of systems with ionic liquids: Measurements and modeling of the binary system fluoroform + 1-ethyl-3-methylimidazolium hexafluorophosphate. J. Supercrit. Fluids 2003, 25, 109-117. [CrossRef]

11. Shiflett, M.B.; Yokozeki, A. Vapor-liquid-liquid equilibria of hydrofluorocarbons + 1-butyl-3-methylimidazolium hexafluorophosphate. J. Chem. Eng. Data 2006, 51, 1931-1939. [CrossRef]

12. Shiflett, M.B.; Yokozeki, A. Solubility differences of halocarbon isomers in ionic liquid [emim][Tf ${ }_{2}$ N]. J. Chem. Eng. Data 2007, 52, 2007-2015. [CrossRef]

13. Álvarez, V.H.; Aznar, M. Thermodynamic modeling of vapor-liquid equilibrium of binary systems ionic liquid + supercritical $\left\{\mathrm{CO}_{2}\right.$ or $\left.\mathrm{CHF}_{3}\right\}$ and ionic liquid + hydrocarbons using Peng-Robinson equation of state. J. Chin. Inst. Chem. Eng. 2008, 39, 353-360. [CrossRef]

14. Shiflett, M.B.; Yokozeki, A. Binary vapor-liquid and vapor-liquid-liquid equilibria of hydrofluorocarbons (HFC-125 and HFC143a) and hydrofluoroethers (HFE-125 and HFE-143a) with ionic liquid [emim][Tf ${ }_{2}$ N]. J. Chem. Eng. Data 2008, 53, $492-497$. [CrossRef]

15. Ren, W.; Scurto, A.M. Phase equilibria of imidazolium ionic liquids and the refrigerant gas, 1,1,1,2-tetrafluoroethane (R-134a). Fluid Phase Equilib. 2009, 286, 1-7. [CrossRef]

16. Ren, W.; Scurto, A.; Shiflett, M.B.; Yokozeki, A. Phase behavior and equilibria of ionic liquids and refrigerants: 1-ethyl-3-methylimidazolium bis(trifluoromethylsulfonyl)imide ([EMim][Tf $\left.{ }_{2} \mathrm{~N}\right]$ ) and R-134a. ACS Symp. Ser. 2009, 1006, 112-128.

17. Yokozeki, A.; Shiflett, M.B. Gas solubilities in ionic liquids using a generic van der Waals equation of state. J. Supercrit. Fluids 2010, 55, 846-851. [CrossRef]

18. Kim, S.; Patel, N.; Kohl, P.A. Performance simulation of ionic liquid and hydrofluorocarbon working fluids for an absorption refrigeration system. Ind. Eng. Chem. Res. 2013, 52, 6329-6335. [CrossRef]

19. Freitas, A.C.D.; Cunico, L.P.; Aznar, M.; Guirardello, R. Modeling vapor liquid equilibrium of ionic liquids + gas binary systems at high pressure with cubic equations of state. Braz. J. Chem. Eng. 2013, 30, 63-73. [CrossRef]

20. Shariati, A.; Ashrafmansouri, S.-S.; Haji Osbuei, M.; Hooshdaran, B. Critical properties and acentric factors of ionic liquids. Korean J. Chem. Eng. 2013, 30, 187-193. [CrossRef]

21. Faúndez, C.A.; Barrientos, L.A.; Valderrama, J.O. Modeling and thermodynamic consistency of solubility data of refrigerants in ionic liquids. Int. J. Refrig. 2013, 36, 2242-2250. [CrossRef]

22. Shiflett, M.B.; Corbin, D.R.; Elliott, B.A.; Yokozeki, A. Sorption of trifluoromethane in zeolites and ionic liquid. J. Chem. Thermodyn. 2013, 64, 40-49. [CrossRef]

23. Kim, S.; Kohl, P.A. Analysis of $[\mathrm{hmim}]\left[\mathrm{PF}_{6}\right]$ and $[\mathrm{hmim}]\left[\mathrm{Tf}_{2} \mathrm{~N}\right]$ ionic liquids as absorbents for an absorption refrigeration system. Int. J. Refrig. 2014, 48, 105-113. [CrossRef]

24. Panah, H.S. Modeling $\mathrm{H}_{2} \mathrm{~S}$ and $\mathrm{CO}_{2}$ solubility in ionic liquids using the CPA equation of state through a new approach. Fluid Phase Equilib. 2017, 437, 155-165. [CrossRef]

25. Shojaeian, A. Thermodynamic modeling of solubility of hydrogen sulfide in ionic liquids using Peng Robinson-Two State equation of state. J. Mol. Liq. 2017, 229, 591-598. [CrossRef]

26. Shojaeian, A.; Fatoorehchi, H. Modeling solubility of refrigerants in ionic liquids using Peng Robinson-Two State equation of state. Fluid Phase Equilib. 2019, 486, 80-90. [CrossRef] 
27. Morais, A.R.C.; Harders, A.N.; Baca, K.R.; Olsen, G.M.; Befort, B.J.; Dowling, A.W.; Maginn, E.J.; Shiflett, M.B. Phase equilibria, diffusivities, and equation of state modeling of HFC-32 and HFC-125 in imidazolium-based ionic liquids for the separation of R-410A. Ind. Eng. Chem. Res. 2020, 59, 18222-18235. [CrossRef]

28. Karakatsani, E.; Economou, I.; Kroon, M.C.; Witkamp, G.-J. TPC-PSAFT modeling of gas solubility in imidazolium-based ionic liquids. J. Phys. Chem. C 2007, 111, 15487-15492. [CrossRef]

29. Chen, Y.; Mutelet, F.; Jaubert, J.-N. Modeling the solubility of carbon dioxide in imidazolium-based ionic liquids with the PC-SAFT equation of state. J. Phys. Chem. B 2012, 116, 14375-14388. [CrossRef] [PubMed]

30. Paduszyński, K.; Domańska, U. Thermodynamic modeling of ionic liquid systems: Development and detailed overview of novel methodology based on the PC-SAFT. J. Phys. Chem. B 2012, 116, 5002-5018. [CrossRef]

31. Alvarez, V.H.; Saldaña, M.D.A. Thermodynamic prediction of vapor-liquid equilibrium of supercritical $\mathrm{CO}_{2}$ or $\mathrm{CHF}_{3}+$ ionic liquids. J. Supercrit. Fluids 2012, 66, 29-35. [CrossRef]

32. Llovell, F.; Oliveira, M.B.; Coutinho, J.A.P.; Vega, L.F. Solubility of greenhouse and acid gases on the $\left[\mathrm{C}_{4} \mathrm{mim}_{[}\left[\mathrm{MeSO}_{4}\right]\right.$ ionic liquid for gas separation and $\mathrm{CO}_{2}$ conversion. Catal. Today 2015, 255, 87-96. [CrossRef]

33. Sun, Y.; Schemann, A.; Held, C.; Lu, X.; Shen, G.; Ji, X. Modeling thermodynamic derivative properties and gas solubility of ionic liquids with ePC-SAFT. Ind. Eng. Chem. Res. 2019, 58, 8401-8417. [CrossRef]

34. Parvaneh, K.; Rasoolzadeh, A.; Shariati, A. Modeling the phase behavior of refrigerants with ionic liquids using the QC-PC-SAFT equation of state. J. Mol. Liq. 2019, 274, 497-504. [CrossRef]

35. Asensio-Delgado, S.; Jovell, D.; Zarca, G.; Urtiaga, A.; Llovell, F. Thermodynamic and process modeling of the recovery of R410A compounds with ionic liquids. Int. J. Refrig. 2020, 118, 365-375. [CrossRef]

36. Albà, C.G.; Vega, L.F.; Llovell, F. Assessment on separating hydrofluoroolefins from hydrofluorocarbons at the azeotropic mixture R513A by using fluorinated ionic liquids: A Soft-SAFT study. Ind. Eng. Chem. Res. 2020, 59, 13315-13324. [CrossRef]

37. Jovell, D.; Gómez, S.B.; Zakrzewska, M.E.; Nunes, A.V.M.; Araújo, J.M.M.; Pereiro, A.B.; Llovell, F. Insight on the solubility of $\mathrm{R} 134 \mathrm{a}$ in fluorinated ionic liquids and deep eutectic solvents. J. Chem. Eng. Data 2020, 65, 4956-4969. [CrossRef]

38. Sousa, J.M.M.V.; Granjo, J.F.O.; Queimada, A.J.; Ferreira, A.G.M.; Oliveira, N.M.C.; Fonseca, I.M.A. Solubilities of hydrofluorocarbons in ionic liquids: Experimental and modelling study. J. Chem. Thermodyn. 2014, 73, 36-43. [CrossRef]

39. Polishuk, I. Implementation of CP-PC-SAFT for predicting thermodynamic properties and gas solubility in 1-alkyl-3methylimidazolium bis(trifluoromethylsulfonyl)imide ionic liquids without fitting binary parameters. Ind. Eng. Chem. Res. 2017, 56, 7845-7857. [CrossRef]

40. Loreno, M.; Reis, R.A.; Mattedi, S.; Paredes, M.L.L. Predicting the solubility of carbon dioxide or methane in imidazolium-based ionic liquids with GC-sPC-SAFT equation of state. Fluid Phase Equilib. 2019, 479, 85-98. [CrossRef]

41. Polishuk, I. Wide-ranging prediction of phase behavior in complex systems by CP-PC-SAFT with universal $k_{\mathrm{ij}}$ values. I. Mixtures of non-associating compounds with $\left[\mathrm{C}_{2} \mathrm{mim}\right]\left[\mathrm{EtSO}_{4}\right],\left[\mathrm{C}_{4} \mathrm{mim}\right]\left[\mathrm{MeSO}_{4}\right]$, and $\left[\mathrm{C}_{2} \mathrm{mim}\right]\left[\mathrm{MeSO}_{3}\right]$ ionic liquids. J. Mol. Liq. 2020, 310, 113266. [CrossRef]

42. Polishuk, I.; Chiko, A.; Cea-Klapp, E.; Garrido, J.M. Implementation of CP-PC-SAFT and CS-SAFT-VR-Mie for predicting thermodynamic properties of $C_{1}-C_{3}$ halocarbon systems. II. Inter-relation between solubilities in ionic liquids, their $P V T$ and critical constants. Ind. Eng. Chem. Res. 2021, 60, 13084-13093. [CrossRef]

43. Polishuk, I. Standardized critical point-based numerical solution of statistical association fluid theory parameters: The perturbed chain-statistical association fluid theory equation of state revisited. Ind. Eng. Chem. Res. 2014, 53, 14127-14141. [CrossRef]

44. Lafitte, T.; Apostolakou, A.; Avendaño, C.; Galindo, A.; Adjiman, C.S.; Müller, E.A.; Jackson, G. Accurate Statistical Associating Fluid Theory for Chain Molecules Formed from Mie Segments. J. Chem. Phys. 2013, 139, 154504. [CrossRef] [PubMed]

45. Gross, J.; Sadowski, G. Perturbed-chain SAFT: An equation of state based on a perturbation theory for chain molecules. Ind. Eng. Chem. Res. 2001, 40, 1244-1260. [CrossRef]

46. Polishuk, I. About the Numerical Pitfalls Characteristic for SAFT EOS Models. Fluid Phase Equilib. 2010, 298, 67-74. [CrossRef]

47. Privat, R.; Gani, R.; Jaubert, J.-N. Are safe results obtained when the PC-SAFT equation of state is applied to ordinary pure chemicals? Fluid Phase Equilib. 2010, 295, 76-92. [CrossRef]

48. Privat, R.; Conte, E.; Jaubert, J.-N.; Gani, R. Are safe results obtained when the PC-SAFT equation of state is applied to ordinary pure chemicals? Part 2: Study of solid-liquid equilibria in binary systems. Fluid Phase Equilib. 2012, 318, 61-76. [CrossRef]

49. Polishuk, I.; Privat, P.; Jaubert, J.-N. Novel methodology for analysis and evaluation of SAFT-Type equations of state. Ind. Eng. Chem. Res. 2013, 52, 13875-13885. [CrossRef]

50. Sun, Y.; Zuo, Z.; Laaksonen, A.; Lu, X.; Ji, X. How to detect possible pitfalls in ePC-SAFT modelling: Extension to ionic liquids. Fluid Phase Equilib. 2020, 519, 112641. [CrossRef]

51. Sun, Y.; Laaksonen, A.; Lu, X.; Ji, X. How to Detect Possible Pitfalls in ePC-SAFT Modeling. 2. Extension to Binary Mixtures of 96 Ionic Liquids with $\mathrm{CO}_{2}, \mathrm{H}_{2} \mathrm{~S}, \mathrm{CO}, \mathrm{O}_{2}, \mathrm{CH}_{4}, \mathrm{~N}_{2}$, and $\mathrm{H}_{2}$. Ind. Eng. Chem. Res. 2020, 59, 21579-21591. [CrossRef]

52. Blas, F.J.; Galindo, A. Study of the high pressure phase behaviour of $\mathrm{CO}_{2}+n$-alkane mixtures using the SAFT-VR approach with transferable parameters. Fluid Phase Equilib. 2002, 194-197, 501-509. [CrossRef]

53. Cismondi, M.; Brignole, E.A.; Mollerup, J. Rescaling of three-parameter equations of state: PC-SAFT and SPHCT. Fluid Phase Equilib. 2005, 234, 108-121. [CrossRef] 
54. Design Institute for Physical Property Research/AIChE. Design Institute for Physical Properties, Sponsored by AIChE. (2005; 2008; 2009; 2010; 2011; 2012; 2015; 2016; 2017; 2018; 2019; 2020). DIPPR Project 801—Full Version. Design Institute for Physical Property Research/AIChE. Available online: https://app.knovel.com/hotlink/toc/id:kpDIPPRPF7/dippr-project-801-full/ dippr-project-801-full (accessed on 9 October 2021).

55. Mejía, A.; Herdes, C.; Müller, E.A. Force fields for coarse-grained molecular simulations from a corresponding states correlation. Ind. Eng. Chem. Res. 2014, 53, 4131-4141. [CrossRef]

56. Polishuk, I.; Chiko, A.; Cea-Klapp, E.; Garrido, J.M. Implementation of CP-PC-SAFT and CS-SAFT-VR-Mie for predicting thermodynamic properties of $\mathrm{C}_{1}-\mathrm{C}_{3}$ halocarbon systems. I. Pure compounds and mixtures with nonassociating compounds. Ind. Eng. Chem. Res. 2021, 60, 9624-9636. [CrossRef]

57. Kumełan, J.; Pérez-Salado Kamps, Á.; Tuma, D.; Maurer, G. Solubility of the single gases carbon monoxide and oxygen in the ionic liquid [hmim][Tf 2 N]. J. Chem. Eng. Data 2009, 54, 966-971. [CrossRef]

58. Florusse, L.J.; Raeissi, S.; Peters, C.J. An IUPAC task group study: The solubility of carbon monoxide in [hmim][Tf $\left.\mathrm{h}_{2} \mathrm{~N}\right]$ at high pressures. J. Chem. Eng. Data 2011, 56, 4797-4799. [CrossRef]

59. Raeissi, S.; Florusse, L.J.; Peters, C.J. Purification of flue gas by ionic liquids: Carbon monoxide capture in [bmim][Tf 2 N]. AIChE J. 2013, 59, 3886-3891. [CrossRef]

60. Kumełan, J.; Pérez-Salado Kamps, Á.; Tuma, D.; Maurer, G. Solubility of CO in the ionic liquid [bmim][PF 6 ]. Fluid Phase Equilib. 2005, 228-229, 207-211. [CrossRef]

61. Afzal, W.; Liu, X.; Prausnitz, J.M. Solubilities of some gases in four immidazolium-based ionic liquids. J. Chem. Thermodyn. 2013, 63, 88-94. [CrossRef]

62. Kumełan, J.; Pérez-Salado Kamps, Á.; Urukova, I.; Tuma, D.; Maurer, G. Solubility of oxygen in the ionic liquid [bmim][PF 6 : Experimental and molecular simulation results. J. Chem. Thermodyn. 2005, 37, 595-602. [CrossRef]

63. Kumełan, J.; Pérez-Salado Kamps, Á.; Tuma, D.; Maurer, G. Solubility of the single gases methane and xenon in the ionic liquid [hmim] [Tf $\left.{ }_{2} \mathrm{~N}\right]$. Ind. Eng. Chem. Res. 2007, 46, 8236-8240. [CrossRef]

64. Raeissi, S.; Peters, C.J. High pressure phase behaviour of methane in 1-butyl-3-methylimidazolium bis(trifluoromethylsulfonyl)imide. Fluid Phase Equilib. 2010, 294, 67-71. [CrossRef]

65. Anthony, J.L.; Maginn, E.J.; Brennecke, J.F. Solubilities and thermodynamic properties of gases in the ionic liquid 1-n-butyl-3methylimidazolium hexafluorophosphate. J. Phys. Chem. B 2002, 106, 7315-7320. [CrossRef]

66. Jalili, A.H.; Safavi, M.; Ghotbi, C.; Mehdizadeh, A.; Hosseini-Jenab, M.; Taghikhani, V. Solubility of $\mathrm{CO}_{2}, \mathrm{H}_{2} \mathrm{~S}$, and their mixture in the ionic liquid 1-octyl-3-methylimidazolium bis(trifluoromethyl)sulfonylimide. J. Phys. Chem. B 2012, 116, 2758-2774. [CrossRef]

67. Rahmati-Rostami, M.; Ghotbi, C.; Hosseini-Jenab, M.; Ahmadi, A.N.; Jalili, A.H. Solubility of $\mathrm{H}_{2} \mathrm{~S}$ in ionic liquids [hmim][PF 6 , [hmim] $\left[\mathrm{BF}_{4}\right]$, and [hmim] [Tf $\left.{ }_{2} \mathrm{~N}\right]$. J. Chem. Thermodyn. 2009, 41, 1052-1055. [CrossRef]

68. Sakhaeinia, H.; Jalili, A.H.; Taghikhani, V.; Safekordi, A.A. Solubility of $\mathrm{H}_{2} \mathrm{~S}$ in ionic liquids 1-ethyl-3-methylimidazolium hexafluorophosphate ([emim] $\left[\mathrm{PF}_{6}\right]$ ) and 1-ethyl-3-methylimidazolium bis(trifluoromethyl)sulfonylimide $\left([\mathrm{emim}]\left[\mathrm{Tf}_{2} \mathrm{~N}\right]\right)$. J. Chem. Eng. Data 2010, 55, 5839-5845. [CrossRef]

69. Jalili, A.H.; Rahmati-Rostami, M.; Ghotbi, C.; Hosseini-Jenab, M.; Ahmadi, A.N. Solubility of $\mathrm{H}_{2} \mathrm{~S}$ in ionic liquids [bmim][PF 6 , [bmim] $\left[\mathrm{BF}_{4}\right]$, and [bmim] [Tf $\left.{ }_{2} \mathrm{~N}\right]$. J. Chem. Eng. Data 2009, 54, 1844-1849. [CrossRef]

70. Jiang, Y.-Y.; Zhou, Z.; Jiao, Z.; Li, L.; Wu, Y.-T.; Zhang, Z.-B. $\mathrm{SO}_{2}$ Gas separation using supported ionic liquid membranes. J. Phys. Chem. B 2007, 111, 5058-5061. [CrossRef]

71. Minnick, D.L.; Shiflett, M.B. Solubility and diffusivity of chlorodifluoromethane in imidazolium ionic liquids: [emim][Tf 2 N], [bmim] $\left[\mathrm{BF}_{4}\right],[\mathrm{bmim}]\left[\mathrm{PF}_{6}\right]$, and [emim][TFES]. Ind. Eng. Chem. Res. 2019, 58, 11072-11081. [CrossRef]

72. Shariati, A.; Gutkowski, K.; Peters, C.J. Comparison of the phase behavior of some selected binary systems with ionic liquids. AIChE J. 2005, 51, 1532-1540. [CrossRef]

73. Yokozeki, A.; Shiflett, M.B. Global phase behaviors of trifluoromethane in ionic liquid [bmim][PF 6 ]. AIChE J. 2006, 52, 3952-3957. [CrossRef]

74. Shiflett, M.B.; Yokozeki, A. Solubility and diffusivity of hydrofluorocarbons in room-temperature ionic liquids. AIChE J. 2006, 52, 1205-1219. [CrossRef]

75. Shiflett, M.B.; Yokozeki, A. Vapor-liquid-liquid equilibria of pentafluoroethane and ionic liquid [bmim][PF 6 mixtures studied with the volumetric method. J. Phys. Chem. B 2006, 110, 14436-14443. [CrossRef]

76. Liu, X.; He, M.; Lv, N.; Qi, X.; Su, C. Vapor-liquid equilibrium of three hydrofluorocarbons with [HMIM][Tf 2 N]. J. Chem. Eng. Data 2015, 60, 1354-1361. [CrossRef]

77. Fallanza, M.; Ortiz, A.; Gorri, D.; Ortiz, I. Propylene and propane solubility in imidazolium, pyridinium, and tetralkylammonium based ionic liquids containing a silver salt. J. Chem. Eng. Data 2013, 58, 2147-2153. [CrossRef]

78. Lepre, L.F.; Andre, D.; Denis-Quanquin, S.; Gautier, A.; Pádua, A.A.H.; Costa Gomes, M.F. Ionic liquids can enable the recycling of fluorinated greenhouse gases. ACS Sustain. Chem. Eng. 2019, 7, 16900-16906. [CrossRef]

79. Sun, Y.; Zhang, Y.; Wang, X.; Prausnitz, J.M.; Jin, L. Vapor-liquid equilibria for R1234ze(E) and three imidazolium-based ionic liquids as working pairs in absorption-refrigeration cycle. J. Chem. Eng. Data 2018, 63, 3053-3060. [CrossRef]

80. Wang, X.; Zhang, Y.; Wang, D.; Sun, Y. Phase equilibria of trans-1,3,3,3-tetrafluoropropene with three imidazolium ionic liquids. J. Chem. Eng. Data 2017, 62, 1825-1831. [CrossRef] 
81. Van Konynenburg, P.H.; Scott, R.L. Critical lines and phase equilibria in binary Van der Waals mixtures. Philos. Trans. R. Soc. Lond. Ser. A 1980, 298, 495-540. [CrossRef]

82. Privat, R.; Jaubert, J.-N. Classification of global fluid-phase equilibrium behaviors in binary systems. Chem. Eng. Res. Des. 2013, 81, 1807-1839. [CrossRef]

83. Shiflett, M.B.; Yokozeki, A. Hydrogen substitution effect on the solubility of perhalogenated compounds in ionic liquid [bmim][PF 6 . Fluid Phase Equilib. 2007, 259, 210-217. [CrossRef]

84. Ren, W.; Scurto, A.M. Global phase behavior of imidazolium ionic liquids and compressed 1,1,1,2-Tetrafluoroethane (R-134a). AIChE J. 2009, 55, 486-493. [CrossRef] 